\title{
THE REDUCTION OF METHYLENE BLUE BY NERVOUS TISSUE.*
}

H. T. RICK EтTS.

(From the Pathological Laboratory of the University of Chicago.)

A NUMBER of years ago Ehrlich pointed out the ability of living cells to decolorize ( $i$.e., reduce) solutions of methylene blue. Later, Neisser and Wechsberg + devised an application of this phenomenon to determine the cytocidal effect of some cellular poisons upon leucocytes. They found that living leucocytes were able to reduce the dye quantitatively, but when they were killed by heat, alcohol, an immune leucotoxic serum, or staphylococcus "leucocidin," they lost this power. Other cells, when fresh (spermatozoa, pancreas, kidney), also reduced the dye, but not after treatment with an injurious agent (alcohol). Living microorganisms had a similar effect, which was lost on treating them with a bactericidal substance. Ferments and bacterial toxins had no reducing power.

I attempted to use this method in determining the toxic effect of an immune neurotoxic serum upon nervous tissue. The serum was prepared by immunizing rabbits and geese with the central nervous system of guinea pigs, and was generally of such strength that 2.0 c.c. intravenously, $0.5-1$ c.c. in the carotid, or $0.01-0.5$ c.c. intracerebrally caused the death of a guinea pig in two to twelve hours. The histological examination of tissues as reported by Ricketts and Rothstein $\$$ shows that this serum produces, intra vitam, profound changes in the nerve cells, while the effects may extend to other tissues as well. In view of the results of Neisser and Wechsberg, it was expected that this "bioscopic" method might be applied here to advantage.

Neisser and Wechsberg placed their mixture of cells, toxin, and methylene blue in small test-tubes, and covered the fluid with

* Received for publication September 14, 1904.

$\dagger$ Münch. med. Wchnschr., 1900, 47, p. 1261; Ztschr. für Hyg., 1901, 36, p. 330.

$\ddagger$ Trans. Checago Path. Soc., 1903, 5, 207. 
liquid paraffin to exclude the air, this being necessary for the accomplishment of reduction. I have found more convenient a tube, suggested by Professor Hektoen, of $4-5 \mathrm{~mm}$. in diameter, drawn to a fine point at either end, which can be sealed in the flame after the tube is filled.

For the first experiments an emulsion of a guinea-pig brain in 30 c.c. of 0.85 per cent. $\mathrm{NaCl}$ was used, the tissue being ground fine with quartz sand, from which it was decanted; later a 5 per cent. emulsion was used uniformly. Aseptic precautions were used throughout and cultures made from the pipettes after the termination of the experiment. That contamination was infrequent may be due in part to bactericidal properties of the emulsion or of the methylene blue, or of both. Experiments which showed contamination were discarded. Reduction was allowed to take place at room temperature.

'There is a quantitative relationship in the reduction of methylene blue by nervous tissue. In one case were used 0.5 c.c. of emulsion and varying quantities of methylene blue $(0.1$ drop to 16 drops of a methylene-blue solution which contained 5 c.c. of a saturated alcoholic solution of the dye and 95 c.c. sterile $\mathrm{NaCl}$ solution). One-tenth to one-half of a drop was completely reduced; in tubes with $0.5-5$ drops partial reduction occurred, the color in succeeding tubes increasing gradually. In the remaining tubes the overlying fluid was densely blue, while the sediment and a very small zone above were decolorized after twenty-four hours. The fact that such an emulsion will reduce methylene blue at all probably indicates that intact cells are not essential. An emulsion kept in the ice-chest for a week will reduce, although less vigorously than when fresh. It occurred to Neisser and Wechsberg that this might be true, for they say: "It is entirely conceivable that certain cells may contain substances which in themselves have a reducing power, without regard to whether the cells as such are living or not."

The reduction is in no case permanent. Tubes after being completely reduced for three days regain the original color when shaken with air.

A drop of formalin added to 0.5 c.c. of the emulsion inhibited 
reduction, so that at the end of three days there was only a trace, the control reducing completely in two hours.

Exposing the emulsion of nervous tissue to a temperature of $70^{\circ} \mathrm{C}$. for thirty minutes destroys its reducing power (Table I). Tubes of the emulsion were treated as indicated in the table; then 1 drop of the methylene-blue solution was added.

TABLE I.

Effect of Heat on the Reducing Power.

$50^{\circ}$ C. for $30 \mathrm{~min}$.

$56^{\circ} \mathrm{C}$. for $30 \mathrm{~min}$.

$60^{\circ}$ C. for $30 \mathrm{~min}$.

$65^{\circ} \mathrm{C}$. for $30 \mathrm{~min}$.

$70-95^{\circ}$ C. for $30 \mathrm{~min}$.

No retardation; complete in $2 \mathrm{hrs}$.

Retarded; not complete in $10 \mathrm{hrs}$.

Retarded; not complete in $10 \mathrm{hrs}$.

Retarded; partial reduction at 18 hrs.; complete at $48 \mathrm{hrs}$.

Other experiments show that the emulsion also loses its reducing power when heated to $98^{\circ} \mathrm{C}$. for five to ten minutes.

Subjecting the nervous tissue to the action of fresh (or activated) neurotoxic serum did not destroy, or even decrease, the reducing power of the emulsion. In Table II the mixtures were sealed at once without allowing time for a preliminary digestive(?) action of the serum upon the nervous tissue.

TABLE II.

The Influence of Neurotoxic Serum on the Reducing Power of Nervovs Tissue. Serum Obtained from Goose after Immunization with Nervous Tissue of Guinea Pig.

\begin{tabular}{|c|c|c|c|c|}
\hline Ermulsion & Serum & $\begin{array}{c}\text { Meth. Blue } \\
\text { Solution }\end{array}$ & & \\
\hline $\begin{array}{c}0.5 \text { c.c. } \\
0.5 \text { c.c. } \\
0.5 \text { c.c. } \\
0.5 \text { c.c. } \\
0.5 \text { c.c. } \\
0.5 \text { c.c. } \\
0\end{array}$ & $\begin{array}{l}0.5 \text { c.c. } \\
0.4 \text { c.c. } \\
0.3 \text { c.c. } \\
0.2 \text { c.c. } \\
0.1 \text { c.c. } \\
0 \\
0.5 \text { c.c. }\end{array}$ & $\begin{array}{c}5 \text { drops } \\
" 6 \\
" 6 \\
6 \\
" 6 \\
"\end{array}$ & 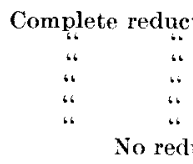 & $\begin{array}{c}\text { in } 18 \mathrm{hrs} . \\
\because: \\
" 6 \\
": \\
": \\
\text { on }\end{array}$ \\
\hline
\end{tabular}

Similar results were obtained when fresh rabbit serum was used in order to add complement, previous experiments having indicated that rabbit serum contains complement for the neurotoxic amboceptor of the goose serum.

Other experiments showed that the addition of neurotoxic 
serum to the nervous-tissue emulsion intensified the reducing power of the latter, rather than inhibiting or destroying it. A tube containing 0.5 c.c. of serum reduced much more quickly than one containing $0.0 \tilde{\text { coce }}$. The serum alone is nonreducing.

Similar results were obtained by treating the nervous tissue with an immune rabbit serum. Digestion of the tissue for six hours with such a serum resulted in an increase in the reducing power, provided the serum was not removed by washing. If, however, the serum had been removed in this manner, the reducing power was decreased. For example:

a) Five c.c. of an emulsion two days old was centrifugated and the overlying fluid drawn off. One and a half c.c. of an active neurotoxin was then added to the sediment and the mixture kept at $37^{\circ} \mathrm{C}$. for two hours, after which it was diluted to the original volume with salt solution.

Test 1.-One c.c. of $a)+1$ drop methylene-blue solution: complete reduction in twelve to twenty-four hours.

Test 2.- - a) was again washed, resulting in the removal of a large part of the serum: no reduction in three days.

b) Same as a), except that normal rabbit serum was substituted for the neurotoxin.

Test 1.-Complete reduction.

Test 2.- No reduction in three days.

c) Same as $a$ ) and $b$ ), except 0.85 per cent. sodium chloride solution was substituted for serum.

Test 1.- Partial reduction.

Test 2.- No reduction in three days.

d) Controls:

1. One c.c. of untreated emulsion reduced.

2. Two c.c. of pure rabbit serum gave no reduction.

It seems, then, that normal serum as well as the immune serum intensifies the reducing power. It is also evident that repeated washing of the emulsion-c), 1 and 2-eliminates its reducing power, the presence of which in the original emulsion is indicated by Control 1. The conditions suggest that in the reduction of methylene blue by the nervous tissue and serum, as well as by the fresh emulsion without serum, there may be a co-operation of two substances, neither of which alone is reducing-c), 2 and Control 2.

Inasmuch as repeated washing of an emulsion inactivated it, 
it seemed probable that separation of the two suspected substances might be accomplished by extraction. Attempts at separation by centrifugating and washing a perfectly fresh emulsion were not successful; but after it had been allowed to extract for one to several days, one of the substances passed into the liquid portion in a state of solution or suspension, the other remaining incorporated with the solid tissue.

In Table III the emulsion had been kept in the ice-chest for eight days.

TABLE III.

Separation of the Reducing Substances in Nervous Tissue by ExtracTION AND WASHING.

\begin{tabular}{|c|c|c|c|}
\hline & $24 \mathrm{hrs}$. & $48 \mathrm{hrs}$. & 72 hrs. \\
\hline 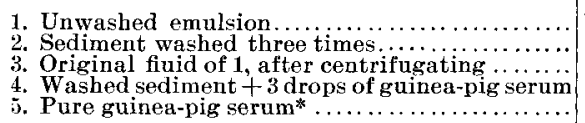 & $\begin{array}{c}\text { Partial reduc. } \\
0 \\
0 \\
\text { Reduced } \\
0\end{array}$ & $\begin{array}{c}\text { Reduced } \\
0 \\
0 \\
0\end{array}$ & $\begin{array}{l}\dddot{\cdots} \\
0 \\
0\end{array}$ \\
\hline
\end{tabular}

It appears, then, that the serum of guinea pig is able to replace the substance which was extracted from the tissue. Normal rabbit serum answers equally well for reactivation.

The extract $\uparrow$ when added to washed sediment caused reduction, althongh either alone did not reduce. Reduction is not so vigorous, however, as when the original emulsion is used, probably because a portion of one or both substances is wasted in the intermediate washings. Filtering the extract through a Berkefeld filter removes the reactivating substance from the fluid. This would seem to indicate either that the substance is in large molecular form, or that it is associated with tissue particles in suspension which are held back by the filter.

The effect of successive washings (which means the progressive removal of the soluble substance) is seen in Table IV. Extraction was allowed to proceed for twenty-four hours in the refrigerator.

* In the course of several days pure serum causes partial reduction of the dye.

$\dagger$ By the "extract" is meant the fluid of a one to several days old emulsion after the sediment has been removed by centrifugation. 
TABLE IV.

The Effect of Repeated Washings on the Reducing Power of the EMULsion.

\begin{tabular}{|c|c|c|c|}
\hline & 12 hours & 24 hours & 72 hours \\
\hline Unwashed emulsion............... & Complete & Complete & Complete \\
\hline $\begin{array}{l}\text { Washed once - no serum ........... } \\
\text { Washed once - serum, } 2 \text { drops..... }\end{array}$ & $\begin{array}{c}0 \\
\text { Complete }\end{array}$ & $\begin{array}{l}\text { Trace reduction } \\
\text { Complete }\end{array}$ & $\begin{array}{l}\text { Trace reduction } \\
\text { Complete }\end{array}$ \\
\hline $\begin{array}{l}\text { Washed twice- no serum } \ldots . . . . . \\
\text { Washed twice-serum, } 2 \text { drops.... }\end{array}$ & $\stackrel{0}{\text { Partial reduction }}$ & $\begin{array}{l}\text { Slight trace } \\
\text { Complete }\end{array}$ & $\begin{array}{l}\text { Trace reduction } \\
\text { Complete }\end{array}$ \\
\hline $\begin{array}{l}\text { Washed } 3 \text { times - no serum ........ } \\
\text { Washed } 3 \text { times - serum, } 2 \text { drops... }\end{array}$ & $\stackrel{0}{\text { Partial reduction }}$ & $\begin{array}{c}0 \\
\text { Almost complete }\end{array}$ & $\stackrel{0}{\text { Complete }}$ \\
\hline Two drops of serum alone......... & 0 & 0 & 0 \\
\hline
\end{tabular}

It is seen that as washing progresses there is a slight tardiness in the reactivation of the sediment by serum.

A fresh emulsion may be inactivated by heating to $98^{\circ}$ for five to ten minutes, or to $70^{\circ}$ for thirty minutes. The soluble substance is hereby destroyed, the one resident in the tissue sediment still being capable of reactivation by serum. The rapidity and completeness of reduction are proportionate to the quantity of serum used for reactivation. In Table $V$ the emulsion was three and one-half days old, and for the experiment was heated to $98^{\circ}$ for ten minutes in order to inactivate its reducing power. Guinea-pig serum four days old, was used to reactivate. The unheated emulsion reduced completely in twenty-four hours. Three drops of the serum alone did not reduce.

TABLE V.

The Ability of Normal Serum of Guinea Pig to Reactivate the Reducing Power, after the Latter Had Been Destroyed bx Heat.

\begin{tabular}{|c|c|c|c|c|c|}
\hline Emulsion & Serum & 6 hours & 24 hours & 48 hours & 72 hours \\
\hline 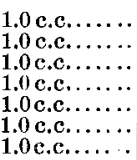 & $\begin{array}{l}0 \\
3 \text { drops } \\
2 \text { drops } \\
1 \text { drop } \\
1 / 2 \text { drop } \\
1 / 4 \text { drop } \\
1 / 10 \text { drop }\end{array}$ & $\begin{array}{c}0 \\
\text { Almost complete } \\
\text { Partial } \\
\text { Trace } \\
0 \\
0 \\
0\end{array}$ & $\begin{array}{c}0 \\
\text { Complote } \\
\text { Almost complete } \\
\text { Marked reduct'n } \\
0 \\
0\end{array}$ & $\begin{array}{c}0 \\
\text { Complete } \\
\because \\
\because \\
\text { Partial } \\
\text { Trace(?) }\end{array}$ & $\begin{array}{c}0 \\
\text { Complete } \\
\because: \\
\because \\
\text { Marked } \\
\text { Trace }\end{array}$ \\
\hline
\end{tabular}

After five to eight days both substances may exist to some extent in the extract, since it is possible to render it reducing by the addition of serum. 
In order to determine whether or not the reactivating power of serum depends on complement, guinea-pig serum was heated to different temperatures, and its reactivating power then tested (Table VI). In this experiment a 5 per cent. emulsion of nervous tissue was extracted for two days, then inactivated by three washings. The serum was from freshly drawn blood.

TABLE VI.

The Effect of Heat upon the Reactivating Power of Normal Serum of Guinfa Pig.

Washed sediment (1.0 c.c. in each tube) to which was added 1, 2, and 3 drops of serum the latter having been heated to the different temperatures for thirty minutes.

The washed sediment in each case was suspended in the original volume of 0.85 per cent. $\mathrm{NaCl}$.

\begin{tabular}{|c|c|c|c|c|}
\hline Temp. & $\begin{array}{c}\text { Observation } \\
\text { Time }\end{array}$ & Serum, 1 Drop & Serum, 2 Drops & Serum, 3 Drops \\
\hline $40^{\circ}$ & $\begin{array}{l}12 \text { hours } \\
20 \\
33\end{array}$ & $\begin{array}{l}\quad 0 \\
\text { Almost complete } \\
\text { Complete }\end{array}$ & Complete & Complete \\
\hline $45^{\circ}$ & $\begin{array}{ll}12 & 16 \\
20 & " 6 \\
33 & " 6\end{array}$ & $\underset{\text { Complete }}{\stackrel{0}{\text { Almost complete }}}$ & Complete & $\begin{array}{l}\text { Slight trace } \\
\text { Complete }\end{array}$ \\
\hline $50^{\circ}$ & $\begin{array}{ll}12 & 4 \\
20 & 6 \\
33 & " 6\end{array}$ & Complete & $\begin{array}{l}\text { Trace } \\
\text { Complete }\end{array}$ & $\begin{array}{l}\text { Trace } \\
\text { Complete }\end{array}$ \\
\hline 55 & $\begin{array}{ll}12 & 4 \\
20 & 4 \\
33 & 4\end{array}$ & Complete & $\begin{array}{l}\text { Partial } \\
\text { Complete }\end{array}$ & $\begin{array}{l}\text { Almost complete } \\
\text { Complete }\end{array}$ \\
\hline 60 & $\begin{array}{ll}12 & 6 \\
20 & 6 \\
33 & 4\end{array}$ & $\begin{array}{c}0 \\
\text { Partial (!) } \\
\text { Partial (?) }\end{array}$ & $\begin{array}{l}\text { Marked } \\
\text { Complete }\end{array}$ & $\begin{array}{l}\text { Almost complete } \\
\text { Complete }\end{array}$ \\
\hline 6.5) & $\begin{array}{ll}12 & 1 . \\
20 & " . \\
33 & .4\end{array}$ & $\begin{array}{l}\text { Trace } \\
\text { Complete }\end{array}$ & $\begin{array}{l}\text { Almost complete } \\
\text { Complete }\end{array}$ & ". \\
\hline 70 & $\begin{array}{ll}12 & 6 \\
20 & 6 \\
33 & 6\end{array}$ & $\begin{array}{l}\text { Almost complete } \\
\text { Complete }\end{array}$ & $\begin{array}{l}\text { Almost complete } \\
\text { Complete }\end{array}$ & "6 \\
\hline
\end{tabular}

Controls. - (1) Unaltered emulsion : complete reduction in twelve hours.

(2) Extract: no reduction in twenty-fouc hours.

(3) Washed sediment; no reduction in thirty-six hours.

(4) Washed sediment + fresh, unheated guinea-pig serum:

\begin{tabular}{|c|c|c|c|}
\hline & 1 Drop & 2 Drops & 3 Drops \\
\hline 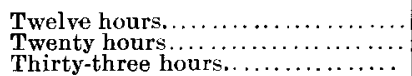 & $\begin{array}{l}\stackrel{0}{\text { Partial }} \\
\text { Complete }\end{array}$ & $\begin{array}{l}\text { Trace } \\
\text { Complete }\end{array}$ & $\begin{array}{l}\text { Marked } \\
\text { Complete }\end{array}$ \\
\hline
\end{tabular}

(5) 3 drops of serum heated to $40-70^{\circ} \mathrm{C}$. for thirty minutes showed no reduction at thirty-three hours. 
In this experiment it is seen that the heating of the serum, rather than destroying the reactivating power, has increased it, in which respect there is no resemblance to ordinary complement. It is also different from the "soluble" substance of the extract as a reactivator, since the latter is destroyed by a temperature of $70^{\circ}$ for thirty minutes. A difference from ordinary complement is also shown by the fact that an old serum will serve to reactivate. Temperatures higher than $70^{\circ}$ were not tried.

Influence of acids and alkalies. - Hydrochloric acid, except when an exceedingly minute amount is added, destroys the reducing powers of the fresh emulsion. It will not reactivate an inactive sediment. Quantities of $0.1-0.2$ c.c. of normal potassium hydrate solution will reactivate the boiled emulsion or the sediment which has been made inactive by washing. Smaller quantities of the alkali have a noticeable, but weaker effect. Potassium hydrate alone does not reduce methylene blue, although it affects the dye chemically, as shown by the appearance of a lavender color.

Influence of tetanus toxin.-Tetanus toxin in any quantity does not affect the reducing power of nervous tissue for methylene blue.

SUMMARY AND CONCLUSIONS.

The "bioscopic" method proved unsuitable as a means of determining the toxic action of neurotoxic serum, owing possibly to the fact that this serum, in common with normal serums, contains properties adjuvant to the reduction of methylene blue.

In the reduction of methylene blue by nervous tissue the living cell is not essential.

Reduction by the tissue emulsion is accomplished by the combined action of two substances, one of which, a thermolabile substance, may be extracted from the tissue by a 0.85 per cent. $\mathrm{NaCl}$ solution; the other, a thermostabile substance, is closely associated with the solid tissue.

Serum, whether it is old, fresh, or heated to $70^{\circ}$ for thirty minutes, may be substituted for the thermolabile substance, as also may potassium hydrate.

Chemists have determined that the reduction of methylene blue 
may be accomplished only by the action of nascent hydrogen on the dye. It becomes leuco-methylene blue when its affinities for hydrogen have been satisfied.*

In the original emulsion this hydrogen may have its source in fermentation processes (glycolytic or proteolytic), since certain ferments and the substances which they specifically affect are known to exist normally in tissues and body fluids.

When serum is used as a reactivator, it is questionable if the reduction can be referred to the action of ordinary ferments in view of the heat resistance of the substance contained in the serum ( $70^{\circ}$ for thirty minutes). The serum may contain, in addition to ferments, some obscure catalyzing agent which acts chemically upon substances contained in the tissue.

It would seem that the action of potassium hydrate must be referred to its catalyzing properties.

It has not been possible to determine the amboceptor and complement nature of the reaction under discussion, since the binding phenomenon could not be demonstrated; however, a degree of analogy is not lacking.

A few experiments performed with 5 per cent. emulsions of liver and kidney tissues indicate that similar principles prevail in the reduction of methylene blue by these tissues.

Although a most interesting chemical problem is concerned in the phenomenon presented, one is confronted with so many unknown substances and reactions that the writer has not thought it profitable at present to follow this work further. It is not unlikely that methylene blue may be made to play the part of an indicator of reduction reactions where sterile substances can be dealt with.

\footnotetext{
* Boiling a solution of glucose and sodium carbonate which contains methylene blue, or the hydrogen evolved by the action of a mineral acid on tin, in a methylene-blue solution, accomplish the reduction of the dye. Potassium ferricyanide reduces, the ferrocyanide oxidizes, the dye.
} 